Transactions of the VŠB - Technical University of Ostrava, Mechanical Series

No. 2, 2016, vol. LXII

article No. 2014

\title{
Karel FRYDRÝŠEK*
}

\section{SIMPLE STATICALLY INDETERMINATE TRUSS (LINEAR, NONLINEAR AND STOCHASTIC APPROACH)}

\section{STATICKY NEURČITÁ PŘÍHRADA (LINEÁRNÍ, NELINEÁRNÍ A STOACHASTISKÝ PŘíSTUP)}

\begin{abstract}
This contribution deals with simple planar and statically indeterminate pin-connected truss. This truss contains 3 members. The ways and methods of derivations and solutions according to theories of $1^{\text {st }}$ and $2^{\text {nd }}$ order are shown. There are applied linear and nonlinear approaches and their simplifications via Maclaurin's series. Programming connected with stochastic Simulation-Based Reliability Assessment Method (i.e. direct Monte Carlo Method) is used for determination of probabilistic reliability assessment (i.e. calculation the probability that plastic deformation occur in members of truss). Finally, the errors of all approaches are evaluated and compared.
\end{abstract}

\section{Abstrakt}

Tento článek se zabývá jednoduchou, rovinnou a staticky neurčitou příhradovou konstrukcí. Př́hrada se skládá z 3 členů. Způsoby a metody odvození a řešení dle teorie prvního a druhého řadu jsou uvedeny. Jsou využity lineární a nelineární prrístupy a jejich zjednodušení přes Maclaurinovy řady. Programování spojené se stochastickou metodou Simulation-Based Reliability Assessment (tj. přímá metoda Monte Carlo), je využito pro určení pravděpodobnostního posudku spolehlivosti (tj. vypočet pravděpodobnosti výskytu plastické deformace $\mathrm{v}$ příhradě). Nakonec byly porovnány a vyhodnoceny chyby všech prŕístupů.

\section{Keywords}

planar truss, theories of $1^{\text {st }}$ and $2^{\text {nd }}$ order, nonlinearities, force and thermal loading, elasticity, plasticity, Simulation-Based Reliability Assessment (SBRA) Method, probabilistic reliability assessment, error estimation

\section{INTRODUCTION}

Planar (i.e. 2D) truss structures appear to be the easiest ways of introducing, explaining and solving geometrical and material nonlinearities; see [1], [2] and [3]. In mechanics, for small deformations, tasks of this type (displacements, strains and stresses etc.) can be solved according to the simple $1^{\text {st }}$ order (linear) theory or the more precise but more demanding $2^{\text {nd }}$ order (nonlinear) theory. The application of 1 st and $2^{\text {nd }}$ order analysis depends upon the deformation of the structure and/or its components under loading. If the effects of deformations of the structure under loadings are negligible with respects to the equilibrium of external and internal forces, $1^{\text {st }}$ order analysis can be applied. Else if the effects of deformations on equilibrium equations are non-negligible, the response (i.e. solution) should be determined using $2^{\text {nd }}$ order analysis.

\footnotetext{
Assoc. Prof., M.Sc., Ph.D., ING-PAED IGIP, Department of Applied Mechanics, Faculty of Mechanical Engineering, VŠB-Technical University of Ostrava, 17. listopadu 15/2172, 70833 Ostrava, Czech Republic, tel. (+420) 59732 3495, e-mail karel.frydrysek@vsb.cz
} 
The $2^{\text {nd }}$ order theory always leads to a nonlinear equation or nonlinear equations which can be solved via several numerical methods. However, there are some possibilities for simplifying it, for example via a Maclaurin series etc. It can then be solved easily and directly with small acceptable error.

Hence, if there are some suitable possibilities to obtain simple solutions of complicated problems, the stochastic approach (such as direct Monte Carlo Method, Simulation-Based Reliability Assessment (SBRA) Method, probabilistic assessment etc.) can also be easily applied. The SBRA Method is a fairly popular and modern trend in mechanics. Hence, a probabilistic reliability assessment can also be performed. For more information see [4], [5], [6] and [7].

This article presents a solution of a simple (2D) statically indeterminate pin-connected truss consisting of three members (i.e. derivation according to the $1^{\text {st }}$ and $2^{\text {nd }}$ order theories, possible simplifications, ways of solution, error estimation) together with their probabilistic inputs, outputs (histograms) and reliability assessment (i.e. calculating the probability that plastic deformation will occur in members of the truss). Finally, the errors of both approaches are evaluated.

\section{SIMPLE PIN-CONNECTED TRUSS CONSISTING OF THREE MEMBERS (STATICALLY INDETERMINATE)}

The simple pin-connected planar truss consisting of three members is loaded by vertical force $\mathrm{F}[\mathrm{N}]$ and by temperature increasing $\Delta_{\mathrm{t}}=\mathrm{t}_{1}-\mathrm{t}_{0}>0[\mathrm{~K}]$ or $\left[{ }^{\circ} \mathrm{C}\right]$; see Fig. 2.1. The material of the members is isotropic, linear and elastic. The truss is loaded in a force-controlled and temperaturecontrolled manner.

Initially, members " 1 " and " 2 " of the truss are in an ideal horizontal position with initial temperature $\mathrm{t}_{0}[\mathrm{~K}]$ or $\left[{ }^{\circ} \mathrm{C}\right]$, and the deformed shape is caused by added force $\mathrm{F}$ and temperature $\mathrm{t}_{1}[\mathrm{~K}]$ or $\left[{ }^{\mathrm{o}} \mathrm{C}\right]$; see Fig. 2.1 .

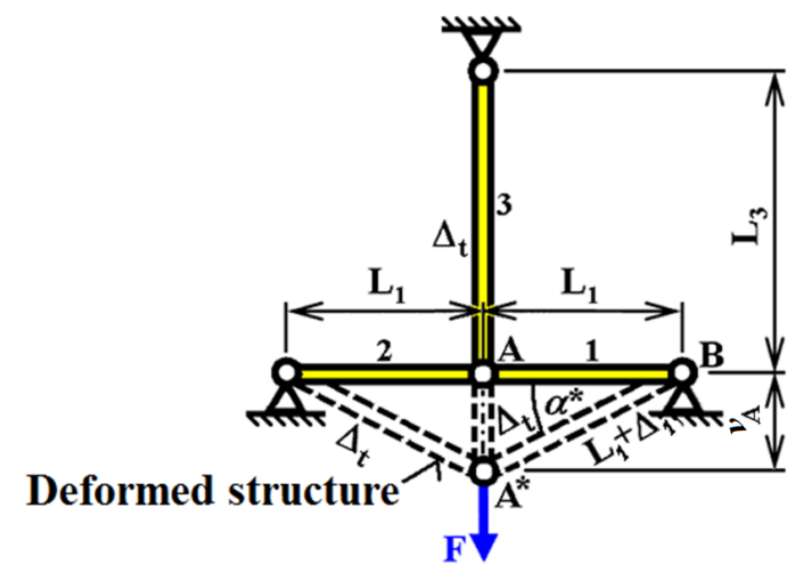

Fig. 2.1 Simple pin-connected truss (statically indeterminate) consisting of three members (loaded by force $\mathrm{F}$ and by uniform temperature increasing $\Delta_{\mathrm{t}}$ )

Expressions are derived for angle $\alpha^{*}[\mathrm{rad}]$, normal forces $N_{\mathrm{i}}[\mathrm{N}]$, axial stresses $\sigma_{\mathrm{i}}[\mathrm{Pa}]$, elongations $\Delta_{\mathrm{i}}[\mathrm{m}]$ in all members $\mathrm{i}=1,2$ and 3 and vertical displacement $v_{\mathrm{A}}[\mathrm{m}]$ according to the theory of small deformations for $1^{\text {st }}$ and $2^{\text {nd }}$ order analyses. The given inputs are force $\mathrm{F}$, length of members $\mathrm{L}_{1}$ and $\mathrm{L}_{3}[\mathrm{~m}]$, modulus of elasticity $E_{1}=E_{2}$ and $E_{3}[\mathrm{~Pa}]$ of the material of the members, area of the cross-sections $A_{1}=A_{2}$ and $A_{3}\left[\mathrm{~m}^{2}\right]$ of the members, global temperature increasing $\Delta_{\mathrm{t}}$ and coefficient of thermal expansion $\alpha_{\mathrm{t} 1}=\alpha_{\mathrm{t} 2}, \alpha_{\mathrm{t} 3}\left[\mathrm{~K}^{-1}\right]$ or $\left[{ }^{\circ} \mathrm{C}^{-1}\right]$. 
Hence, the angle $\alpha^{*}$ is unknown and is connected with the deformed structure. By applying the Method of Joints at point " $A$ " of the deformed structure $\left(2^{\text {nd }}\right.$ order theory; see Fig.2.2b), the equations for normal forces can be derived as

$$
\left.\begin{array}{l}
N_{1} \cos \alpha^{*}-N_{2} \cos \alpha^{*}=0 \\
\Rightarrow \quad N_{1}=N_{2}, \\
N_{1} \sin \alpha^{*}+N_{2} \sin \alpha^{*}+N_{3}-\mathrm{F}=0 \\
\Rightarrow 2 N_{1} \sin \alpha^{*}+N_{3}-\mathrm{F}=0 .
\end{array}\right\}
$$

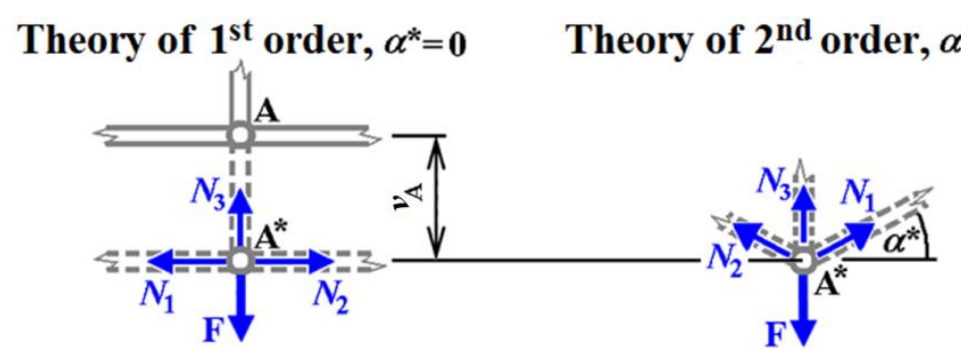

Fig. 2.2 Normal forces (theory of $1^{\text {st }}$ and $2^{\text {nd }}$ order)

Let is the value of angle $\alpha^{*}$ small. Hence $\alpha^{*}=0$ (i.e. the angular changes are neglected, $\sin \alpha^{*}=0$ and $\cos \alpha^{*}=1$; see Fig.2.2a; is substituted in eq. (2.1) the simple formulas for the theory of $\mathbf{1}^{\text {st }}$ order can be derived. Hence, $N_{3}=\mathrm{F}$ and the members " 1 " and " 2 " do not change their length (i.e. deformation boundary condition $\Delta_{1}=\Delta_{2}=\frac{N_{1} \mathrm{~L}_{1}}{E_{1} A_{1}}+\alpha_{\mathrm{t} 1} \Delta_{\mathrm{t}} \mathrm{L}_{1}=0 \Rightarrow$ $\left.N_{1}=N_{2}=-\alpha_{\mathrm{t} 1} \Delta_{\mathrm{t}} E_{1} A_{1}\right)$.

The elongation of member " 3 " is equal to movement of point "A". Thus $v_{\mathrm{A}}=\Delta_{3}=\frac{N_{3} \mathrm{~L}_{3}}{E_{3} A_{3}}+\alpha_{\mathrm{t} 3} \Delta_{\mathrm{t}} \mathrm{L}_{3}=\left(\frac{N_{3}}{E_{3} A_{3}}+\alpha_{\mathrm{t} 3} \Delta_{\mathrm{t}}\right) \mathrm{L}_{3}$.

According to the theory of $2^{\text {nd }}$ order, for the solution of this statically indeterminate structure, two deformation boundary condition should be added. These conditions follows from right-angled triangle A, ${ }^{*}$, B ; see Fig. 2.3.

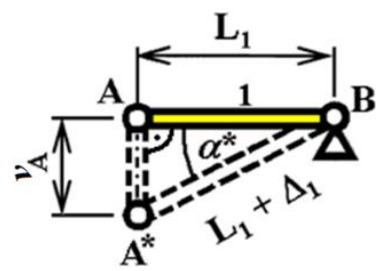

Fig. 2.3 Deformation boundary conditions (theory of $2^{\text {nd }}$ order)

Hence $\cos \alpha^{*}=\frac{\mathrm{L}_{1}}{\mathrm{~L}_{1}+\Delta_{1}}=\frac{\mathrm{L}_{1}}{\mathrm{~L}_{1}+\frac{N_{1} \mathrm{~L}_{1}}{E_{1} A_{1}}+\alpha_{\mathrm{t} 1} \Delta_{\mathrm{t}} \mathrm{L}_{1}} \Rightarrow$ 


$$
N_{1}=N_{2}=\frac{E_{1} A_{1}\left[1-\left(1+\alpha_{\mathrm{t} 1} \Delta_{\mathrm{t}}\right) \cos \alpha^{*}\right]}{\cos \alpha^{*}}
$$

and $\tan \alpha^{*}=\frac{v_{\mathrm{A}}}{\mathrm{L}_{1}}=\frac{\Delta_{3}}{\mathrm{~L}_{1}}=\frac{\frac{N_{3} \mathrm{~L}_{3}}{E_{3} A_{3}}+\alpha_{\mathrm{t} 3} \Delta_{\mathrm{t}} \mathrm{L}_{3}}{\mathrm{~L}_{1}} \Rightarrow$

$$
N_{3}=E_{3} A_{3}\left(\frac{\mathrm{L}_{1}}{\mathrm{~L}_{3}} \tan \alpha^{*}-\alpha_{\mathrm{t} 3} \Delta_{\mathrm{t}}\right) \text {. }
$$

Equations (2.2) and (2.3) can be substituted into (2.1). Hence, after simplification, the following nonlinear dependence can be derived; see eq. (2.4).

$$
\left(2 E_{1} A_{1}\left[1-\left(1+\alpha_{\mathrm{t} 1} \Delta_{\mathrm{t}}\right) \cos \alpha^{*}\right]+\frac{E_{3} A_{3} \mathrm{~L}_{1}}{\mathrm{~L}_{3}}\right) \tan \alpha^{*}-\mathrm{F}-\alpha_{\mathrm{t} 3} \Delta_{\mathrm{t}} E_{3} A_{3}=0
$$

Finally, the solution according to the $1^{\text {st }}$ order theory and $2^{\text {nd }}$ order theory is given in the Tab. 2.1.

Tab. 2.1 Results of the theory of small deformations $\left(1^{\text {st }}\right.$ and $2^{\text {nd }}$ order theory)

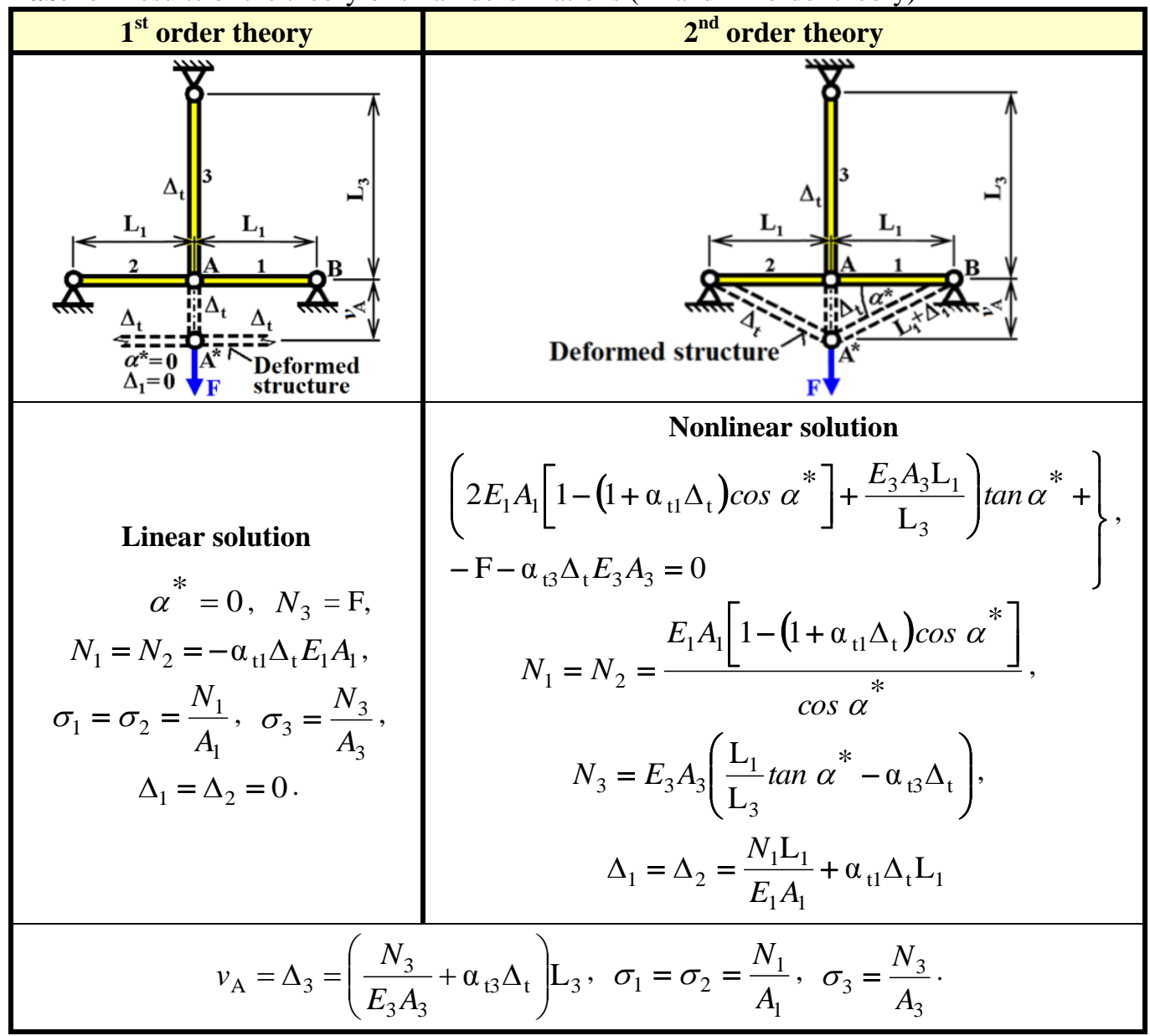


Note that the same results as written in Tab. 2.1 can be derived in many other ways. One of these ways is based on the minimum of total potential energy $\Pi[\mathrm{J}]$ of the truss (i.e. on equation $\left.\frac{\partial \Pi}{\partial \alpha^{*}}=0\right)$.

Another example (i.e. statically determinate truss) is presented in reference [3].

\section{SIMPLE NUMERICAL SOLUTION}

For the theory of $2^{\text {nd }}$ order, a reasonably good initial estimate of angle $\alpha^{*}$ (i.e. $\alpha_{0}^{*}$ ) can be derived by simplification via a Maclaurin series where $\tan \alpha^{*} \approx \alpha_{0}^{*}$ and $\cos \alpha^{*} \approx 1-\frac{\alpha_{0}^{* 2}}{2}$. Hence, trigonometric eq. (2.4) can be simplified into polynomial equation

$$
\alpha_{0}^{* 3}+\frac{E_{3} A_{3} \mathrm{~L}_{1}-2 E_{1} A_{1} \alpha_{\mathrm{t} 1} \Delta_{\mathrm{t}} \mathrm{L}_{3}}{E_{1} A_{1} \mathrm{~L}_{3}\left(1+\alpha_{\mathrm{t} 1} \Delta_{\mathrm{t}}\right)} \alpha_{0}^{*}-\frac{\mathrm{F}+\alpha_{\mathrm{t} 3} \Delta_{\mathrm{t}} E_{3} A_{3}}{E_{1} A_{1}\left(1+\alpha_{\mathrm{t} 1} \Delta_{\mathrm{t}}\right)}=0
$$

Cubic eq. (3.1) can be solved via Cardano's formula; see [8]. Because the discriminant

$$
\overline{\mathrm{D}}=\left(\frac{\mathrm{F}+\alpha_{\mathrm{t} 3} \Delta_{\mathrm{t}} E_{3} A_{3}}{2 E_{1} A_{1}\left(1+\alpha_{\mathrm{t} 1} \Delta_{\mathrm{t}}\right)}\right)^{2}+\left(\frac{E_{3} A_{3} \mathrm{~L}_{1}-2 E_{1} A_{1} \alpha_{\mathrm{t} 1} \Delta_{\mathrm{t}} \mathrm{L}_{3}}{3 E_{1} A_{1} \mathrm{~L}_{3}\left(1+\alpha_{\mathrm{t} 1} \Delta_{\mathrm{t}}\right)}\right)^{3}>0,
$$

the eq. (3.1) has only one real root

$$
\alpha_{0}^{*}=\sqrt[3]{\frac{\mathrm{F}+\alpha_{\mathrm{t} 3} \Delta_{\mathrm{t}} E_{3} A_{3}}{2 E_{1} A_{1}\left(1+\alpha_{\mathrm{t} 1} \Delta_{\mathrm{t}}\right)}+\sqrt{\overline{\mathrm{D}}}}+\sqrt[3]{\frac{\mathrm{F}+\alpha_{\mathrm{t} 3} \Delta_{\mathrm{t}} E_{3} A_{3}}{2 E_{1} A_{1}\left(1+\alpha_{\mathrm{t} 1} \Delta_{\mathrm{t}}\right)}-\sqrt{\overline{\mathrm{D}}}}
$$

From eq. (2.4) (by isolating trigonometric function $\tan \alpha^{*}$ ) follows $\tan \alpha^{*}=\frac{\mathrm{F}+\alpha_{\mathrm{t} 3} \Delta_{\mathrm{t}} E_{3} A_{3}}{2 E_{1} A_{1}\left[1-\left(1+\alpha_{\mathrm{t} 1} \Delta_{\mathrm{t}}\right) \cos \alpha^{*}\right]+\frac{E_{3} A_{3} \mathrm{~L}_{1}}{\mathrm{~L}_{3}}} \quad$ and then can be derived

$$
\alpha^{*}=\operatorname{atan}\left(\frac{\mathrm{F}+\alpha_{\mathrm{t} 3} \Delta_{\mathrm{t}} E_{3} A_{3}}{2 E_{1} A_{1}\left[1-\left(1+\alpha_{\mathrm{t} 1} \Delta_{\mathrm{t}}\right) \cos \alpha^{*}\right]+\frac{E_{3} A_{3} \mathrm{~L}_{1}}{\mathrm{~L}_{3}}}\right) \cdot
$$

Thus, the iterative scheme with recursive relation (i.e. the application of the Fixed Point Iteration Method) can be derived as

$$
\left.\begin{array}{l}
\alpha_{\mathrm{j}+1}^{*}=\operatorname{atan}\left(\frac{\mathrm{F}+\alpha_{\mathrm{t} 3} \Delta_{\mathrm{t}} E_{3} A_{3}}{2 E_{1} A_{1}\left[1-\left(1+\alpha_{\mathrm{t} 1} \Delta_{\mathrm{t}}\right) \cos \alpha_{\mathrm{j}}^{*}\right]+\frac{E_{3} A_{3} \mathrm{~L}_{1}}{\mathrm{~L}_{3}}}\right), \\
\text { for } \mathrm{j}=0,1,2, \ldots
\end{array}\right\}
$$

Hence, with small and acceptable error (for small deformations, according to the $2^{\text {nd }}$ order theory), a good solution can be written as $\alpha^{*} \cong \alpha_{1}^{*}$, i.e. 


$$
\alpha^{*} \cong \operatorname{atan}\left(\frac{\mathrm{F}+\alpha_{\mathrm{t} 3} \Delta_{\mathrm{t}} E_{3} A_{3}}{2 E_{1} A_{1}\left[1-\left(1+\alpha_{\mathrm{t} 1} \Delta_{\mathrm{t}}\right) \cos \alpha_{0}^{*}\right]+\frac{E_{3} A_{3} \mathrm{~L}_{1}}{\mathrm{~L}_{3}}}\right)
$$

Correctness of the derived results (i.e. their error) can be checked via Pythagoras' theorem too, i.e. $\left(\mathrm{L}_{1}+\Delta_{1}\right)^{2}=v_{\mathrm{A}}^{2}+\mathrm{L}_{1}^{2}$; see Fig.2.3.

\section{PROBABILISTIC INPUTS}

For a solution using a stochastic approach, calculating the probability that plastic deformation will occur and performing a probabilistic reliability assessment, the probabilistic inputs must be defined; see Tab. 4.1 and 4.2. Anthill software (i.e. the SBRA Method, direct Monte Carlo approach) was applied in this stochastic modelling; see references [4], [5], [6], [7], [9], [10], [11] and [12].

Tab. 4.1 Stochastic inputs and their basic characteristics (simple pin-connected truss, statically indeterminate, Anthill 2.6 software)

\begin{tabular}{|c|c|c|c|c|c|c|}
\hline \begin{tabular}{c|} 
Random \\
inputs
\end{tabular} & Description & $\begin{array}{l}\text { Histogram applied in Anthill } \\
\text { software }\end{array}$ & Min. & Max. & Median & Mean \\
\hline $\mathrm{L}_{1}[\mathrm{~m}]$ & $\begin{array}{l}\text { Length of } \\
\text { members } \\
\text { "1" and "2" }\end{array}$ & "Uniform" distribution & 0.95 & 1.05 & 1 & 1 \\
\hline $\mathrm{L}_{3}[\mathrm{~m}]$ & $\begin{array}{l}\text { Length of } \\
\text { member "3" }\end{array}$ & $\begin{array}{c}\text { "Uniform" distribution } \\
\text { (n) }\end{array}$ & 2.90 & 3.1 & 3 & 3 \\
\hline$E_{1}[\mathrm{~Pa}]$ & $\begin{array}{l}\text { Modulus of } \\
\text { elasticity of } \\
\text { members } \\
\text { "1" and "2" }\end{array}$ & $\begin{array}{l}\text { Modified (truncated) normal } \\
\text { distribution } \\
2.08 \times 10^{11 * " n 1-05 . d i s "}\end{array}$ & $1.976 \times 10^{11}$ & $2.184 \times 10^{11}$ & $2.080 \times 10^{11}$ & $2.080 \times 10^{11}$ \\
\hline$E_{3}[\mathrm{~Pa}]$ & $\begin{array}{l}\text { Modulus of } \\
\text { elasticity of } \\
\text { member "3" }\end{array}$ & $\begin{array}{c}\text { Modified (truncated) normal } \\
\text { distribution } \\
2.08 \times 10^{11} * \text { "n1-05.dis" }\end{array}$ & $1.976 \times 10^{11}$ & $2.184 \times 10^{11}$ & $2.080 \times 10^{11}$ & $2.080 \times 10^{11}$ \\
\hline$A_{1}\left[\mathrm{~m}^{2}\right]$ & $\begin{array}{l}\text { Area of } \\
\text { cross- } \\
\text { section of } \\
\text { members } \\
\text { "1" and "2" }\end{array}$ & $\begin{array}{l}\text { Modified (truncated) normal } \\
\text { distribution } 0.022 * \text { n1-05.dis" }\end{array}$ & 0.0209 & 0.0231 & 0.0220 & 0.0220 \\
\hline$A_{3}\left[\mathrm{~m}^{2}\right]$ & $\begin{array}{c}\text { Area of } \\
\text { cross- } \\
\text { section of } \\
\text { member " } 3 \text { " }\end{array}$ & $\begin{array}{l}\text { Modified (truncated) normal } \\
\text { distribution } 2 \times 10^{-3} * \text { "n1-04.dis" }\end{array}$ & 0.002016 & 0.002184 & 0.0021 & 0.0021 \\
\hline $\mathrm{F}[\mathrm{N}]$ & $\begin{array}{l}\text { External } \\
\text { vertical } \\
\text { force acting } \\
\text { in joint "A" }\end{array}$ & $\begin{array}{c}\text { Modified (truncated) dead } \\
\text { distribution } \\
550000 * \text { "dead1.dis" }\end{array}$ & 449900 & 550000 & 500147 & 499950 \\
\hline
\end{tabular}


Tab. 4.2 Stochastic inputs and their basic characteristics (simple pin-connected truss, statically indeterminate, Anthill 2.6 software)

\begin{tabular}{|c|c|c|c|c|c|c|}
\hline $\begin{array}{c}\text { Random } \\
\text { inputs }\end{array}$ & Description & $\begin{array}{c}\text { Histogram applied in Anthill } \\
\text { software }\end{array}$ & Min. & Max. & Median & Mean \\
\hline$R_{\mathrm{p}}[\mathrm{MPa}]$ & $\begin{array}{l}\text { Yield limit } \\
\text { for material } \\
\text { of members } \\
\text { "1", "2" and } \\
\text { "3" }\end{array}$ & $\begin{array}{l}\text { Measurement for A36-M steel } \\
\text { (truncated user defined } \\
\text { distribution) "a36-m-cont.dis" }\end{array}$ & 248 & 500 & 338.29 & 339.15 \\
\hline $\mathrm{t}_{0}\left[{ }^{\mathrm{o}} \mathrm{C}\right]$ & $\begin{array}{c}\text { Initial } \\
\text { temperature } \\
\text { of members } \\
\text { "1", "2" and } \\
\text { "3" }\end{array}$ & "temperature-t0.dis", user defined & -8 & 27 & 9.820 & 9.755 \\
\hline $\mathrm{t}_{1}\left[{ }^{\mathrm{o}} \mathrm{C}\right]$ & $\begin{array}{c}\text { Initial } \\
\text { temperature } \\
\text { of members } \\
\text { "1", "2" and } \\
\text { "3" }\end{array}$ & "temperature-t1.dis", user defined & 10 & 30 & 20.181 & 20.144 \\
\hline$\alpha_{t 1}\left[{ }^{0} \mathrm{C}^{-1}\right]$ & $\begin{array}{l}\text { Coefficient } \\
\text { of thermal } \\
\text { expansion } \\
\text { of members } \\
\text { "1" and "2" }\end{array}$ & $\begin{array}{l}\text { Modified (truncated) normal } \\
\text { distribution 1.2e-5*"n1-05.dis" }\end{array}$ & $1.14 \times 10^{-5}$ & $1.26 \times 10^{-5}$ & $1.2 \times 10^{-5}$ & $1.2 \times 10^{-5}$ \\
\hline$\alpha_{\mathrm{t} 2}\left[{ }^{0} \mathrm{C}^{-1}\right]$ & $\begin{array}{l}\text { Coefficient } \\
\text { of thermal } \\
\text { expansion } \\
\text { of member } \\
\text { "3" }\end{array}$ & $\begin{array}{l}\text { Modified (truncated) normal } \\
\text { distribution 1.2e- } 5 * \text { "n1-05.dis" }\end{array}$ & $1.14 \times 10^{-5}$ & $1.26 \times 10^{-5}$ & $1.2 \times 10^{-5}$ & $1.2 \times 10^{-5}$ \\
\hline
\end{tabular}

Thirteen chosen probabilistic inputs (i.e. mutually independent variables) of random type, and their notation via histograms, are shown in Tab. 4.1 and 4.2. These random variables cover real variabilities and fluctuations in technical practice for the truss presented here.

Tab. 4.1 and 4.2 presents all basic statistical information (i.e. minimum, maximum, median and mean values) and histograms. In Anthill software, the histogram "Uniform" means truncated uniform distribution, "n1-04.dis" means truncated normal distribution $\pm 4 \%$, "n1-05.dis" means truncated normal distribution $\pm 5 \%$, "dead1.dis" means dead load truncated distribution ${ }_{-18.9 \%}^{+0 \%}$, "a36m-cont.dis" means asymmetric yield stress truncated distribution for carbon steel A36, "temperaturet0.dis" means truncated and asymmetric user distribution ${ }_{-181.47 \%}^{+174.95 \%}$ and "temperature-t1.dis" means truncated and asymmetric user distribution ${ }_{-50.45 \%}^{+48.65 \%}$; see [5], [6] and [9].

Thus, the given stochastic inputs are used to calculate the stochastic outputs $\Delta_{\mathrm{t}},{ }^{*}, v_{\mathrm{A}}, N_{1,2,3}$, $\sigma_{1,2,3}$, and $\Delta_{1,2,3}$ via histograms and distributed functions, as presented in Tab. 4.1 and 4.2. All calculations are performed and evaluated for $\mathrm{N}_{\text {TOTAL }}=10^{7}$ Monte Carlo random simulations. 


\section{PROBABILISTIC OUTPUTS}

The stochastic (probabilistic) results (i.e. stochastic outputs), see Tab. 5.1 and 5.2, can be used for the probabilistic reliability assessment of the solved truss (Anthill software, SBRA Method; see [5], [6] and [9]).

Tab. 5.1 Stochastic outputs and their basic characteristics (simple pin-connected truss, statically indeterminate, Anthill 2.6 software, result of $10^{7}$ Monte Carlo random simulations)

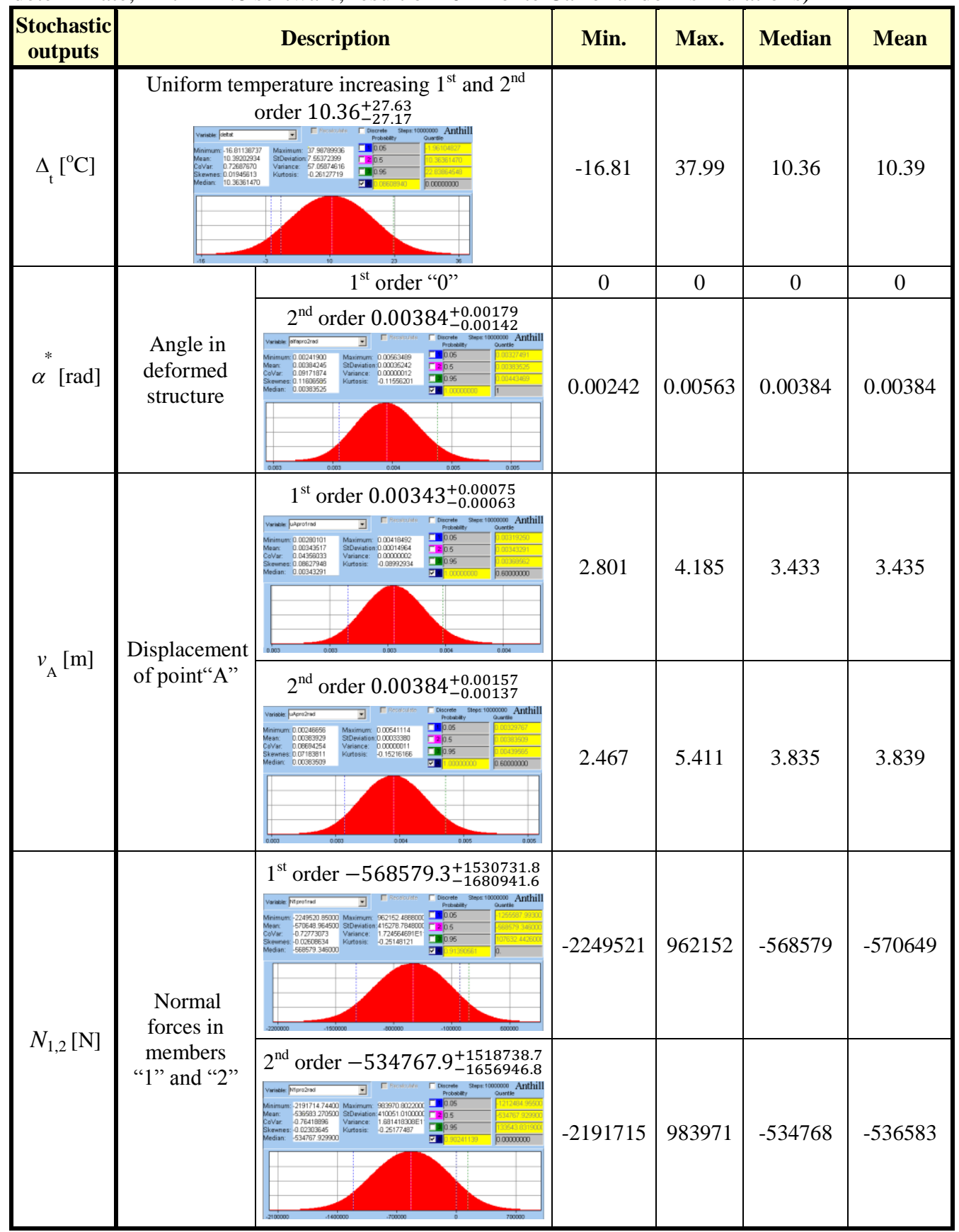


Tab. 5.2 Stochastic outputs and their basic characteristics (simple pin-connected truss, statically indeterminate, Anthill 2.6 software, result of $10^{7}$ Monte Carlo random simulations)

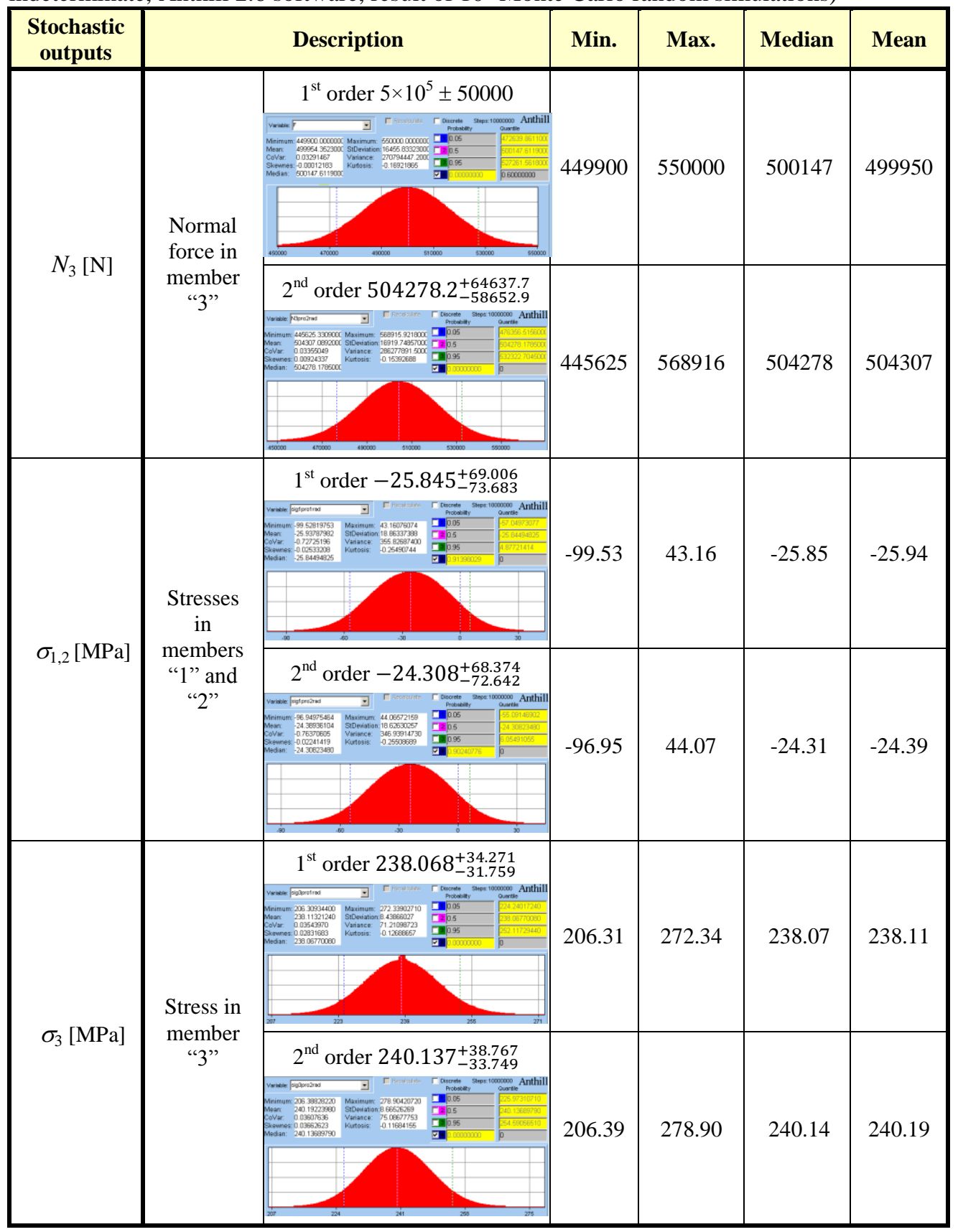

Negative values of $N_{1}=N_{2}$ and $\sigma_{1}=\sigma_{2}$ mean compression state of loading. However, in this case, there can be tensile or compression states in members "1" and "2"; see Tab. 5.1 and 5.2.

In this case, the reliability functions $R_{F \mathrm{i}}[\mathrm{MPa}]$ can be defined as

$$
R_{F 1}=R_{\mathrm{P}}-\left|\sigma_{1}\right|, \quad R_{F 3}=R_{\mathrm{P}}-\sigma_{2} .
$$



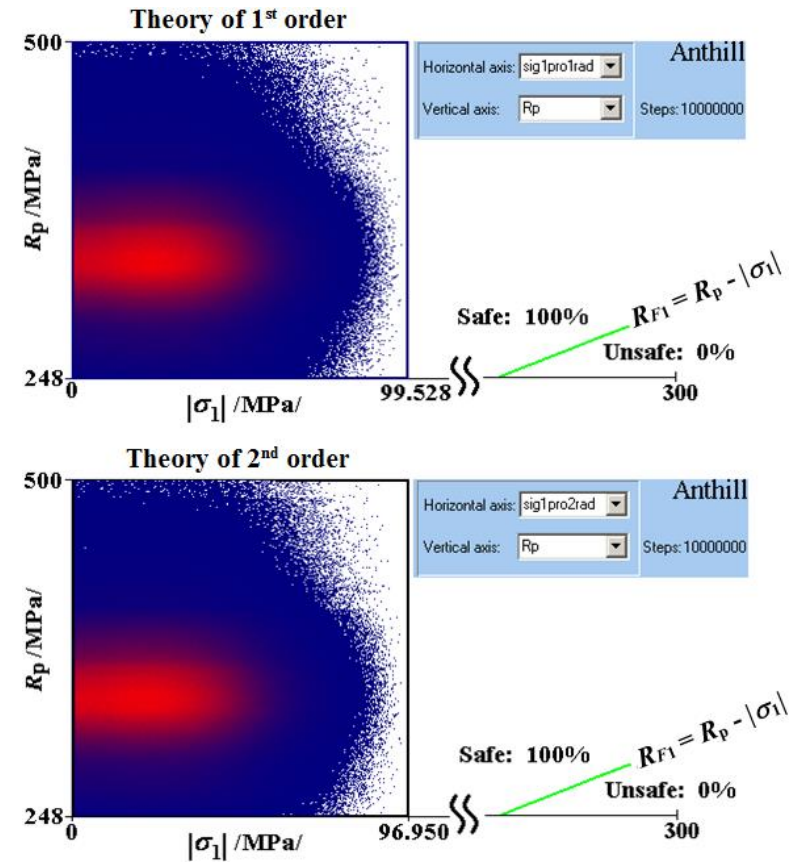

Fig. 5.1 Probabilistic reliability assessment for members "1" and "2" (SBRA Method, simple pinconnected truss, statically indeterminate, Anthill 2.6 software, result of $10^{7}$ Monte Carlo random simulations)

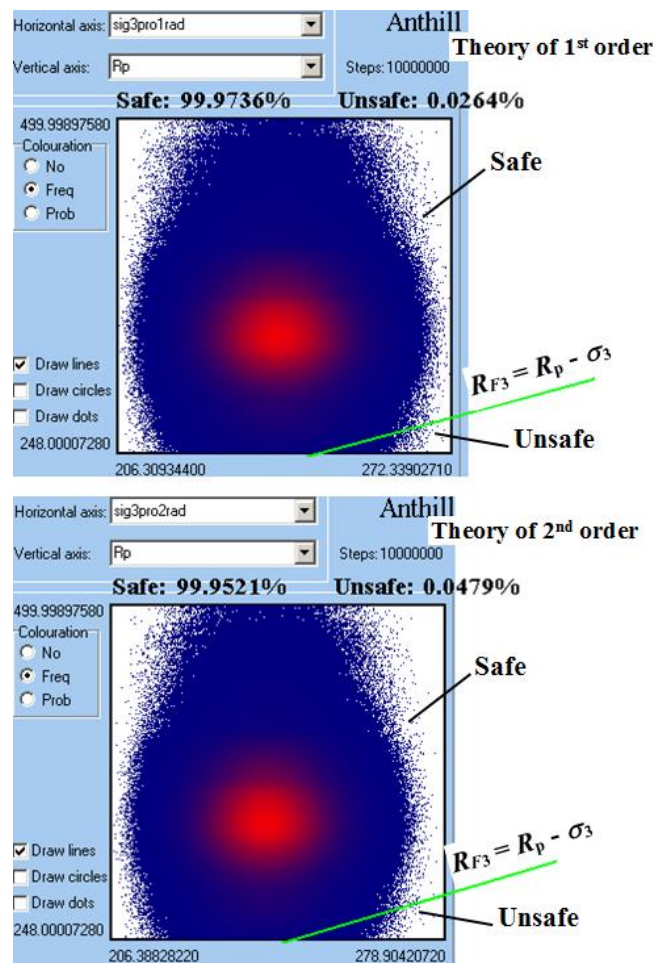

Fig. 5.2 Probabilistic reliability assessment for member "3" (SBRA Method, simple pin-connected truss, statically indeterminate, Anthill 2.6 software, result of $10^{7}$ Monte Carlo random simulations) 
The reliability functions (i.e. $2 \mathrm{D}$ histograms $\left|\sigma_{1}\right|$ vs. $R_{\mathrm{p}}$ and $\sigma_{3}$ vs. $R_{\mathrm{p}}$ ) are presented in Fig. 5.1 and 5.2. Hence, it is evident that if $R_{F \mathrm{i}}>0$ (i.e. yield limit $R_{\mathrm{p}}$ is greater than positive value of normal stress $\sigma_{\mathrm{i}}$ ), the stress is below the yield limit (safe loading, no plasticity occurs). Otherwise, if $R_{F \mathrm{i}} \leq 0$, then plasticity occurs (i.e. an unsafe and undesirable situation); see Fig. 5.3.

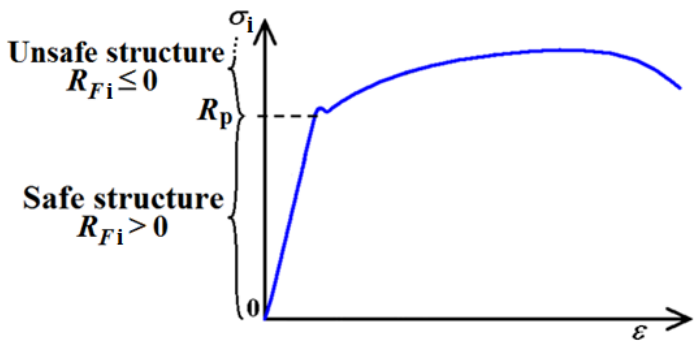

Fig. 5.3 Stress-strain diagram of material - definition of safe and unsafe structure

\section{PROBABILISTIC RELIABILITY ASSESSMENT}

The probability $P_{f}$ of an unsafe situation (i.e. a situation when $R_{F \mathrm{i}} \leq 0$ ) is calculated in Anthill software by the expression

$$
P_{f}=\max \left(P_{f \mathrm{i}}\right), \text { where } P_{f \mathrm{i}}=P_{\left(R_{F \mathrm{i}} \leq 0\right)}=\frac{\mathrm{N}_{f \mathrm{i}}}{\mathrm{N}_{\text {TOTAL }}}
$$

and where $\mathrm{N}_{f \mathrm{i}}$ is the number of unfavorable states (i.e. states when $R_{F \mathrm{i}} \leq 0$ ) and, in our case, $\mathrm{N}_{\text {TOTAL }}=10^{7}$ Monte Carlo random simulations.

In the case of $1^{\text {st }}$ order theory, from the presented results it is calculated that $P_{f}=P_{f 2}=P_{f 3}=2.6444 \times 10^{-4}$ (i.e. approx. $0.0264 \%$ of all possible random simulations cause plastic deformations).

In the case of $2^{\text {nd }}$ order theory, from the presented results it is calculated that $P_{f}=P_{f 2}=P_{f 3}=4.7938 \times 10^{-4}$ (i.e. approx. $0.0479 \%$ of all possible random simulations cause plastic deformations).

Finally, the probabilistic reliability assessment can be performed by checking the inequation

$$
P_{f} \leq P_{\text {ALLOWABLE. }}
$$

In the case of $1^{\text {st }}$ order theory, the inequation (6.2) is fulfilled (i.e. $2.6444 \times 10^{-4}<4 \times 10^{-4}$ ); the solved truss therefore satisfies the probabilistic reliability condition.

However, in the case of $2^{\text {nd }}$ order theory, the inequation (6.2) is not fulfilled (i.e. $4.7938 \times 10^{-4}>4 \times 10^{-4}$ ); the solved truss therefore does not satisfy the probabilistic reliability condition.

There is possible to calculate percentage error of calculations $\Delta_{\%}[\%]$, for example, by comparing median values of the results from the theory of $2^{\text {nd }}$ and $1^{\text {st }}$ order (Tab. 5.1 and 5.2). Thus

$$
\Delta_{\%}=100 \frac{\text { value }_{2 \mathrm{nd} \text { order }}-\text { value }_{1 \mathrm{st} \text { order }}}{\text { value }_{2 \mathrm{nd} \text { order }}} .
$$

From calculated results is obvious the legitimacy application of the theory of $2^{\text {nd }}$ order which gives results close to the reality. Some errors of the theory of $\mathbf{1}^{\text {st }}$ order are alarming; see Tab. 6.1. 
Tab. 6.1 Errors of the theory of $1^{\text {st }}$ order in comparing with the theory of $2^{\text {nd }}$ order (simple pinconnected truss, statically indeterminate)

\begin{tabular}{|c|c|}
\hline Description & $\Delta_{\%}[\%]$ \\
\hline Error of median values for angle $\alpha^{*}$ according to the theory of $1^{\text {st }}$ order & $\mathbf{1 0 0}$ \\
\hline Error of median values for displacement $v_{\mathrm{A}}$ according to the theory of $1^{\text {st }}$ order & $\mathbf{1 0 . 4 8}$ \\
\hline Error of median values for normal forces $N_{1}=N_{2}$ according to the theory of $1^{\text {st }}$ order & $\mathbf{- 6 . 3 2}$ \\
\hline Error of median values for normal force $N_{3}$ according to the theory of $1^{\text {st }}$ order & $\mathbf{0 . 8 2}$ \\
\hline Error of median values for stresses $\sigma_{1}=\sigma_{2}$ according to the theory of $1^{\text {st }}$ order & $\mathbf{- 6 . 3 2}$ \\
\hline Error of median values for stress $\sigma_{3}$ according to the theory of $1^{\text {st }}$ order & $\mathbf{0 . 8 6}$ \\
\hline $\begin{array}{c}\text { Error of median values for probability of unsafe state } P_{f 1} \text { according to the theory of } \\
1^{\text {st }} \text { order }\end{array}$ & $\mathbf{0}$ \\
\hline $\begin{array}{c}\text { Error of median values for probability of unsafe state } P_{f}=P_{f 2}=P_{f 3} \text { according to the } \\
\text { theory of } 1^{\text {st }} \text { order }\end{array}$ & $\mathbf{4 4 . 8 4}$ \\
\hline
\end{tabular}

\section{CONCLUSIONS}

It is a fact that, the planar truss structures appear to be the easiest ways of introducing, explaining and solving geometrical and material nonlinearities (in this case, a simple pin-connected and statically indeterminate truss of three members). The focus is on the understanding, step-by-step derivation, applications, possible simplifications, programming and solution of nonlinear problems which are widely applied mostly by civil and mechanical engineers. The solutions according to the $2^{\text {nd }}$ order theory always lead to a set of nonlinear equations. However, there are possibilities to solve such a task directly via iterative approaches, or to linearize and simplify it (via a Maclaurin series in this case) and then to solve it easily with only small errors. Simplifying a relatively complicated nonlinear set of equations usually enables a relatively easy application. The stochastic approach (direct Monte Carlo Method, Simulation-Based Reliability Assessment (SBRA) Method, probabilistic reliability assessment) is a modern, quite popular trend in mechanics. Hence, the SBRA Method (i.e. stochastic inputs and outputs) was applied in order to determine the probability that plastic deformations will occur in the structure. Finally, a probabilistic reliability assessment was performed by checking the inequation $P_{f} \leq P_{A L L O W A B L E}$ (i.e. the probability that plastic deformation will occur).

In the case of $1^{\text {st }}$ order theory (i.e. linear solution), the solved truss satisfies the probabilistic reliability condition. However, in the case of $2^{\text {nd }}$ order theory (i.e. nonlinear solution), the solved truss does not satisfy the probabilistic reliability condition). Hence, from calculated results is obvious the legitimacy application of the theory of $2^{\text {nd }}$ order which gives results close to the reality. Some mentioned errors of the theory of $1^{\text {st }}$ order are alarming.

This article was supported by the Czech project SP2016/145.

\section{REFERENCES}

[1] BAŽANT, Z.P., CEDOLIN, L. Stability of Structures: Elastic, Inelastic, Fracture and Damage Theories, Oxford University Press, New York, 1991, $3^{\text {rd }}$ ed., 2010, pp. 1-1011

[2] DUNAISKI, P., GALISHNIKOVA, V., PAHL, P.J. Geometrically Nonlinear Analysis of Plane Trusses and Frames, ISBN 9781920109486, AFRICAN SUN MeDIA, 2009, pp. 1-382. 
[3] FRYDRÝŠEK, K. Basic Strength and Elasticity of Materials, ISBN 978-80-248-3870-0, Faculty of Mechanical Engineering, VŠB-Technical University of Ostrava, Ostrava, Czech Republic, 2016, pp. 1-264.

[4] FRYDRÝŠEK, K. Probabilistic Approaches Applied in the Solution of Problems in Mining and Biomechanics, In: ENGINEERING MECHANICS 2011, pp. 151-154, Svratka, 2011, ISBN 978-80-87012-33-8.

[5] MAREK, P., BROZZETTI, J., GUŠTAR, M., TIKALSKY, P. et al. Probabilistic Assessment of Structures Using Monte Carlo Simulation Background, Exercises and Software, (2 ${ }^{\text {nd }}$ extended edition), ISBN 80-86246-19-1, ITAM CAS, Prague, Czech Republic, 2003, pp. 1471.

[6] MAREK, P., GUŠTAR, M., ANAGNOS, T. et al. Simulation-Based Reliability Assessment for Structural Engineers, CRC Press, Boca Raton, USA, 1995, ISBN 0-8493-8286-6, pp. 1365.

[7] LOKAJ, A., KLAJMONOVÁ, K. A Probability Assessment of the Carrying Capacity of Round Timber Joints, In: Advances in Civil Engineering and Building Materials IV - Selected and Peer Reviewed Papers from the $20144^{\text {th }}$ International Conference on Civil Engineering and Building Materials, CEBM, 2014, ISBN 978-113800088-9, pp 373-378.

[8] BARTSCH, H.J. Handbook of Mathematical Formulas, Academic Press, New York, NY, 1974, ISBN: 978-0-12-080050-6, pp. 1-525, http://dx.doi.org/10.1016/B978-0-12-0800506.50001-4.

[9] http://www.sbra-anthill.com/

[10] LOKAJ, A., MAREK, P. Simulation-Based Reliability Assessment of Timber Structures, In: Proceedings of the $12^{\text {th }}$ International Conference on Civil, Structural and Environmental Engineering Computing, ISBN 978-190508830-0, Funchal, Madeira, Portugal, 2009, pp. 1-18.

[11] TVRDÁ, K. Probability and Sensitivity Analysis of Plate, Applied Mechanics and Materials, vol. 617, Svratka, Czech Republic, 2014, ISBN 978-3-03835-197-9, ISSN 1660-9336, pp. 193-196, DOI: 10.4028/www.scientific.net/AMM.617.193.

[12] ECSI, L., JANČO, R., ELESZTOS, P. An Improved Thermal-Structural Finite Element Model for Manufacturing Processes with Heat Generation, ENGINEERING MECHANICS 2014, $20^{\text {th }}$ International Conference on Engineering Mechanics, 2014, ISBN 978-80-214-4871-1, ISSN 1805-8248, pp. 156-159. 